\title{
Format Kelembagaan Kerjasama Antar Daerah untuk Pembangunan Ekonomi Kawasan Berkelanjutan
}

\author{
BAMBANG TRI HARSANTOㅁ, SLAMET ROSYADI ${ }^{2}$, SIMIN $^{3}$ \\ 1,2,3) Jurusan IImu Administrasi Negara, Fisip Unsoed. Jl HR Bunyamin No. 993, Purwokerto Jateng 53122 \\ 1,2,3) email: slametrosyadi72@gmail.com
}

\begin{abstract}
Abstrak. This study was aimed at examining in depth the various weaknesses and efforts to improve the format of interregional cooperation better, and examining in depth perception, practice collaboration and document of inter-regional cooperation. To address these objectives, this study applied qualitative research methods: Multiple Case Study. This study will discuss various strategies, actions and opinions of actors cooperation in responding to various constraints and weaknesses in the former format of cooperation. The results showed each region considers that decentralization of regional cooperation is indispensable for the development efforts of regional economic potential. However, the existence of inter-regional cooperation is highly dependent on the commitment of the head of local governments and the support of government agencies in both the provincial and central government, particularly in the form of funding and legislation that is used as an umbrella law for cooperation between regions.
\end{abstract}

Keywords: interregional cooperation, commitment of the head of local government, institutional form

\begin{abstract}
Abstrak. Penelitian ini bertujuan untuk mengkaji secara mendalam berbagai kelemahan dan upaya perbaikan format kerjasama antar daerah yang lebih baik, dan mengkaji secara mendalam persepsi, praktik kerjasama dan dokumen kerjasama antar daerah. Untuk menjawab kedua tujuan tersebut digunakan metode penelitian Multiple Case Study, dimana kajian ini akan membahas berbagai strategi, tindakan dan opini dari para pelaku kerjasama dalam merespon berbagai kendala dan kelemahan dalam format kerjasama yang telah dirumuskan sebelumnya. Hasil penelitian menunjukkan masing-masing daerah menganggap bahwa di era otonomi daerah kerjasama antar daerah sangat diperlukan bagi upaya pengembangan potensi ekonomi daerah. Namun demikian, eksistensi kerjasama antar daerah sangat tergantung pada komitmen dari kepala daerah serta dukungan dari lembaga pemerintahan di atasnya baik propinsi maupun pemerintah pusat, terutama dalam bentuk dukungan pendanaan dan peraturan perundangan yang digunakan sebagai payung hukum adanya kerjasama antar daerah.
\end{abstract}

Kata kunci: Kerjasama antar daerah, komitmen kepala daerah, format kelembagaan

\section{Pendahuluan}

Dalam satu dekade terakhir, kerjasama antar pemerintah daerah di Indonesia telah berkembang sebagai bentuk tata kelola baru dalam era desentralisasi. Sebelumnya, otonomi daerah lebih dipahami sebagai kepentingan otonom daerah yang tidak memperhatikan konteks yang lebih luas atau daerah lain yang berdekatan (Keban, 2009). Padahal, otonomi daerah dapat berperan sebagai sebuah instrumen untuk mewujudkan kesejahteraan dan kerjasama yang ideal diantara berbagai pemerintah daerah (Surkati, 2012). Sebagai akibatnya, berbagai praktik kontradiktif yang dilandasi dengan spirit persaingan lebih berkembang daripada kooperatif. Namun demikian, setelah berlakunya UU No. 32 Tahun 2004 tentang Pemerintah Daerah yang kemudian direvisi dengan UU No. 23 Tahun 2014, maka kompetisi antar daerah telah bergeser menjadi kerjasama antar daerah.

Berkembangnya kesadaran pemerintah daerah untuk bekerjasama dengan pemerintah

Received: 4 Februari 2015, Revision: 13 Mei 2015, Accepted: 22 Juni 2015

Print ISSN: 0215-8175; Online ISSN: 2303-2499. Copyright@2015. Published by Pusat Penerbitan Universitas (P2U) LPPM Unisba

Terakreditasi SK Kemendikbud, No.040/P/2014, berlaku 18-02-2014 s.d 18-02-2019 
daerah lainnya didasari atas beberapa motif. Blair dan Janousek (2013) melaporkan bahwa kerjasama antar pemerintah daerah didorong untuk menjawab persoalan bersama dan kebutuhan-kebutuhan situasional sehingga tersedia opsi alternatif dalam penyelenggaraan pelayanan publik. Jeremias T. Keban (2009), mengidentifikasikan sejumlah alasan dibalik kerjasama antar pemerintah daerah:

(1) kerjasama menghasilkan energi yang lebih besar khususnya untuk mengatasi persoalan bersama yang tidak dapat diatasi sendiri, (2) kerjasama mendorong proses belajar bersama untuk kemajuan bersama, (3) kerjasama mendorong praktik transparansi diantara pihakpihak yang bekerjasama, dan (4) kerjasama akan menghilangkan sikap egoistik daerah, sehingga yang akan berkembang adalah visi kebersamaan antar pemerintah daerah.

Salah satu model kerjasama antar pemerintah daerah di Indonesia adalah forum kerjasama antara lima kabupaten di Jawa Tengah: Banjarnegara, Purbalingga, Banyumas, Cilacap, dan Kebumen, yang kemudian dikenal dengan sebutan BARLINGMASCAKEB. Menurut Tim Peneliti KPPOD (2013), dibentuk pada 2003 yang merupakan pioner bagi kerjasama dalam bidang perdagangan. Dalam hal ini, BARLINGMASCAKEB memfasilitasi media pemasaran bagi para produsen pertanian untuk memperluas akses dan mempromosikan produk yang dihasilkan. Dengan model tersebut, transaksi ekonomi mengalami peningkatan dan berdampak positif bagi perekonomian daerah.

Setelah berjalan lebih dari satu dekade, dinamika BARLINGMASCAKEB menunjukkan tanda-tanda kemunduran. Forum kerjasama lima pemerintah daerah tersebut tidak lagi berfungsi sejak 2011. Pergantian kepemimpinan daerah tidak otomatis memiliki kepentingan yang sama dengan para pemimpin daerah terdahulu yang telah menggagas pembentukan forum kerjasama BARLINGMASCAKEB. Selain faktor kepemimpinan, faktor-faktor lain yang menentukan kerjasama antar daerah adalah kepentingan politik elit pemerintahan, kapasitas anggaran, budaya dan struktur birokrasi (Masriadi, 2014) dan modal sosial (Fiisabiilillah, Vidayani, dan Hudalah, 2014). Studi sebelumnya menemukan bahwa salah satu faktor krusial yang menghambat kerjasama antar daerah di wilayah BARLINGMASCAKEB adalah format kelembagaan kerjasama itu sendiri (Harsanto, 2012). Atas dasar hal tersebut diperlukan adanya suatu penelitian untuk merumuskan format baru lembaga kerja sama antar darah. Dengan format kelembagaan saat ini hasil kerjasama yang dicapai tidak maksimal, terkonsentrasi pada suatu wilayah tertentu dan melemahkan komitmen kerjasama antar pemerintah daerah (Harsanto, 2012). Penelitian ini memfokuskan pada upaya menggali dan mendeskripsikan pandangan dan pengalaman aktor-aktor pemerintah daerah yang terlibat dalam kerjasama antar daerah dan stakeholders bisnis maupun masyarakat terkait dengan format kelembagaan yang ideal berbasis pada pengembangan kawasan.

Penelitian ini dilakukan di lima kabupaten yang tergabung dalam lembaga kerjasama antar daerah BARLINGMASCAKEB yang meliputi Kabupaten Banjarnegara, Purbalingga, Banyumas, Cilacap, dan Kebumen, dilakukan mulai April-Oktober 2014. Sumber data berasal dari data primer dan data sekunder. Data primer diperoleh dari hasil wawancara mendalam dengan para informan, yang dipilih dengan cara purposif. Informan terdiri dari staf Bappeda, Kabag Perekonomian, Kabag Pemerintahan, pengusaha, dan anggota DPRD. Untuk mendukung data primer, berbagai sumber data sekunder seperti dokumen dan laporan perkembangan kerjasama forum BARLINGMASCAKEB juga dimanfaatkan untuk mendapatkan gambaran terakhir dinamika kerjasamanya. Analisis data kualitatif dalam penelitian ini menggunakan teknik analisis interaktif (Miles dan Huberman, 1994) yang dimulai dengan proses pengumpulan data, reduksi data, tampilan data dan verifikasi serta penarikan kesimpulan. Proses analisis tidak dilakukan secara bertahap atau linear tetapi dinamis disesuaikan dengan kebutuhan dan kelengkapan data. Validitas data menggunakan teknik triangulasi.

\section{Identifikasi Penyebab Rendahnya Kinerja Lembaga Kerjasama}

Dari hasil penggalian data di lapangan, kegagalan lembaga kerjasama antar daerah BARLINGMASCAKEB dalam mewujudkan tujuannya dapat diidentifikasi faktor penyebabnya karena beberapa hal sebagai berikut. Pertama, faktor eksternal yaitu kurangnya dukungan dari pemerintah baik pusat maupun provinsi. Kedua, faktor internal yaitu kurangnya komitmen dari pimpinan daerah dan lemahnya aspek pengelolaan kegiatan dari lembaga kerjasama antar daerah. Berikut deskripsi faktor penyebab rendahnya kinerja lembaga kerjasama antar daerah BARLINGMASCAKEB. 


\section{Kurangnya Dukungan Pemerintah}

Kurangnya dukungan dari pemerintah baik pusat maupun provinsi terhadap keberadaan lembaga kerjasama antar daerah juga menjadi faktor kendala tidak optimalnya lembaga tersebut dalam menjalankan aktivitasnya. Dukungan pemerintah baik pusat maupun provinsi dapat berupa dukungan pembuatan peraturan perundangan sebagai dasar legal formal bahwa keberadaan lembaga kerjasama antardaerah memang diatur dalam peraturan perundangan. Dukungan juga dapat diberikan dalam bentuk pengawasan dan pembinaan maupun pemberian bantuan pendanaan.

Berdasarkan PP No. 50 Tahun 2007 pembiayaan lembaga kerjasama antar daerah menjadi tanggungjawab kepala daerah. Melalui Permendagri Nomor 22 Tahun 2011 tentang Pedoman Penyusunan Anggaran Pendapatan dan Belanja Daerah Tahun Anggaran 2012 diperjelas bahwa yang dimaksud tanggungjawab kepala daerah dalam pembiayaan lembaga kerjasama antar daerah berupa pemberian alokasi anggaran dari APBD melalui pos belanja hibah. Sampai pada tahap ini, isi dari peraturan perundangan yang mengatur mengenai lembaga kerjasama antar daerah masih konsisten. Namun dengan keluarnya Permendagri No. 32 Tahun 2011 tentang Pedoman Pemberian Hibah dan Bantuan Sosial yang Bersumber Dari Anggaran Pendapatan Belanja Daerah, dana belanja hibah tidak lagi dapat diberikan kepada lembaga kerjasama antar daerah. Permendagri tersebut sama sekali tidak membuka ruang bagi lembaga kerjasama antar daerah untuk dapat menerima kucuran dana APBD untuk membiayai kegiatannya.

Berdasarkan Permendagri No. 23 Tahun 2009 Tentang Tata Cara Pembinaan dan Pengawasan Kerjasama Antar Daerah, pasal 3 menyebutkan gubernur melakukan pembinaan dan pengawasan atas kerjasama antardaerah kabupaten / kota di wilayahnya. Namun dalam prakteknya peran tersebut tidak pernah dijalankan. Masing-masing lembaga kerjasama antar daerah berjalan dan berkreasi sendiri tanpa arahan dari pemerintah provinsi.

\section{Kurangnya Komitmen Pimpinan Daerah}

Pada awal pembentukannya, Forum Regional yang beranggotakan para bupati bersepakat untuk menyelenggarakan rapat Forum Regional dengan agenda membuat kebijakan umum dan mengevaluasi kinerja dari Dewan Eksekutif. Dalam praktiknya komitmen untuk selalu menghadiri rapat Forum Regional mulai menurun. Dengan alasan kesibukan kerja, rapat Forum Regional tidak lagi dapat diselenggarakan sekali dalam setahun namun bisa menjadi sekali dalam dua tahun.

Pada level yang lebih rendah, Dewan Eksekutif yang beranggotakan para Kepala Bappeda di masing-masing kabupaten dengan ketua salah satu bupati yang ditunjuk oleh Forum Regional, dalam menyelenggarakan agenda rapat tidak selalu dapat dihadiri oleh para anggotanya. Ketua Dewan Eksekutif tidak pernah menghadiri rapat Dewan Eksekutif, dan para anggota Dewan Eksekutif lebih sering mewakilkan kehadirannya pada kegiatan rapat-rapat Dewan Eksekutif. Dalam banyak kasus Rapat Dewan Eksekutif tidak dapat membuat keputusan karena ketidakhadiran dari para anggotanya.

\section{Lemahnya Pengelolaan Kegiatan Lembaga Kerjasama Antar Daerah}

Tidak terintegrasinya kegiatan yang dilakukan oleh Regional Management dengan kegiatan yang dilakukan oleh SKPD di masing-masing daerah juga menjadi faktor penyumbang penting rendahnya kinerja lembaga kerjasama antar daerah. Untuk bisa menghasilkan kinerja outcome sebagaimana yang diharapkan, peran SKPD terkait sangat penting karena merekalah yang memiliki sumberdaya manusia dan sumberdaya keuangan untuk bisa menjalankan fungsi pembangunan. Dalam konteks pembangunan regional, tujuan pembangunan bisa dicapai apabila SKPD terkait dari masing-masing kabupaten bekerjasama untuk menyelesaikan permasalahan yang menyangkut bidang mereka namun berskala lintas daerah. Selama ini agenda program kegiatan dari lembaga kerjasama antar daerah hanya dilakukan oleh regional manager tanpa melibatkan SKPD dari masing-masing daerah. Dengan kata lain aktivitas yang dilakukan oleh lembaga kerjasama antar daerah belum mampu menumbuhkan aktivitas "aksi bersama" (collective action) bagi penyelesaian masalah pembangunan pada tingkatan regional.

\section{Analisis Kritis Dimensi Kelembagaan}

Pada bagian ini akan dideskripsikan hasil analisis faktor yang memengaruhi kinerja lembaga kerjasama antar daerah BARLINGMASCAKEB dari aspek kelembagaan. Variabel yang 
akan dianalisis meliputi, format kerjasama, pengelolaan kerjasama, struktur organisasi, kerangka regulasi, sumber pendanaan dan sistem pendukung.

\section{Format Kerjasama}

Pilihan pola kelembagaan dari lembaga kerjasama antar daerah BARLINGMASCAKEB yang dilakukan oleh para penggagasnya adalah dalam bentuk "Lembaga Kerjasama". Pilihan ini sudah tepat, mengingat ada dua tujuan yang hendak dicapai yaitu (1) tujuan pembangunan, dengan penekanan pada sinkronisasi dan pensinergian program pembangunan ekonomi antar daerah; (2) tujuan pemasaran, yang lebih menekankan pada pemasaran produk-produk lokal. Pencapaian dua tujuan ini sangat membutuhkan format kelembagaan dalam bentuk Lembaga Kerjasama, karena format ini memiliki kewenangan, lingkup otoritas dan pola relasi antar anggota yang dapat mendukung pencapaian tujuan tersebut.

Namun demikian, di dalam prakteknya format kelembagaan lembaga kerjasama antar daerah BARLINGMASCAKEB dalam bentuk "Lembaga Kerjasama" ini tidak bisa berjalan dengan baik untuk mencapai tujuan. Hal ini disebabkan "Lembaga Kerjasama" tidak menjalankan kewenangan yang dimilikinya secara penuh, hanya memiliki lingkup otoritas yang terbatas serta pola relasi antar anggota yang sangat cair.

Ada empat kewenangan yang seharusnya dijalankan kelembagaan kerjasama antar daerah dalam bentuk "Lembaga Kerjasama", yaitu; (1) Information networks: forum yang berfungsi sebagai pertukaran informasi mengenai kebijakan dan program, teknologi dan solusi potensial atas masalah-masalah bersama; (2) Developmental networks: Adanya keterlibatan anggota yang lebih tinggi, tidak hanya sekedar pertukaran informasi tetapi dikombinasikan dengan pendidikan dan pelayanan yang secara langsung meningkatkan kapasitas informasi daerah untuk melaksanakan solusi atas masing-masing persoalannya; (3) outreach networks: jaringan antar daerah lebih solid dengan adanya program strategi untuk masing-masing daerah yang diadopsi dan dilaksanakan di daerah lain; dan (4) action networks: daerah-daerah secara bersamasama membuat serangkaian program aksi bersama-sama yang dijalankan oleh masing-masing daerah sesuai dengan proporsi dan kemampuannya masing-masing
(Agranof dan McGuire, 2003). "Lembaga Kerjasama" BARLINGMASCAKEB seharusnya menjalankan kewenangan tersebut sampai pada tahapan action networks, namun dalam kenyataannya kewenangan yang dijalankan hanya pada tahapan Information networks, Developmental networks dan outreach networks saja.

"Lembaga Kerjasama" seharusnya juga memiliki lingkup otoritas yang kuat dalam bentuk pengaturan yang ketat terhadap anggota dengan sanksi yang tegas bagi yang melanggar kesepakatan. Dalam praktiknya, pengaturan yang ketat terhadap anggota tidak pernah dibuat dan setiap ada pelanggaran kesepakatan selalu diselesaikan dengan caracara persuasif dengan semangat kemitraan.

"Lembaga Kerjasama" juga menuntut adanya pola relasi dalam bentuk pelibatan anggota yang tinggi dalam upaya memecahkan permasalahan bersama. Namun, dalam praktiknya aktivitas ini tidak pernah dilakukan. Semua kegiatan dijalankan Regional Manager sementara masing-masing pemerintah daerah tinggal menunggu hasilnya. Dari fakta ini dapat dikatakan bahwa dari aspek format kerja sama, lembaga kerjasama antar daerah BARLINGMASCAKEB memiliki struktur dalam bentuk "Lembaga Kerjasama" namun fungsi yang dijalankan tidak sebagaimana yang dipersyaratkan. Kondisi ini menjadi faktor penyumbang rendahnya kinerja dari lembaga kerjasama antar daerah tersebut.

\section{Pengelolaan Kerjasama}

Pada umumnya pengelolaan kerjasama antardaerah baik di Indonesia maupun di beberapa negara terbagi kedalam dua pola yaitu pengelolaan oleh tenaga profesional dan pengelolaan yang terintegrasi pada pemerintahan daerah. Pada pengelolaan profesional, pengelolaan lembaga kerjasama dilimpahkan kepada kelompok profesional yang direkrut secara khusus untuk mengelola aktivitas kerjasama. Dalam beberapa kasus model ini sangat memercepat terjadinya proses kerjasama antar daerah karena kepercayaan anggota terhadap pengelola cukup tinggi karena mereka dianggap independen tidak memihak kepada salah satu anggota. Kelemahannya, aktivitas yang dilakukan oleh lembaga kerjasama ini sulit terintegrasi dengan unit-unit kerja di pemerintah daerah.

Pengelolaan oleh pemerintah daerah adalah pengelolaan kerjasama antar daerah yang sepenuhnya melekat dalam unit- 
unit reguler pemerintah tanpa melibatkan tenaga profesional. Model ini tidak terlalu memercepat terjadinya proses kerjasama antar daerah karena sangat berpeluang terjebak dalam logika birokrasi dalam proses pengembangan kerjasama antardaerah. Di samping itu, tingkat kepercayaan angota rendah terhadap pelaksana karena dianggap tidak netral terhadap salah satu anggota. Hanya saja dalam model ini mempunyai kekuatan yaitu tingginya tingkat integrasi antara aktivitas kerjasama antardaerah dengan unit-unit kerja di pemerintah daerah karena pengelolaannya memang di bawah pemerintah daerah.

Pengelola lembaga kerjasama antar daerah BARLINGMASCAKEB dilakukan oleh tenaga profesional yaitu oleh Regional Manager beserta jajarannya yang dipilih melalui mekanisme fit and proper test. Pada awalnya kepercayaan anggota terhadap kinerja pengelola cukup tinggi. Namun sebagaimana kelemahan dari pengelolaan oleh tenaga profesional, aktivitas yang dilakukan oleh lembaga kerjasama antar daerah ini tidak terintegrasi dengan unit kerja di pemerintah daerah. Hal ini menyebabkan kinerja yang dicapai tidak sesuai sebagaimana yang diharapkan. Akibatnya, kepercayaan anggota terhadap kinerja pengelola menjadi rendah.

Pada kasus pengelolaan kerjasama antar daerah BARLINGMASCAKEB sebaiknya dilakukan dengan menggabungkan antara pengelolaan oleh tenaga profesional dengan pengelolaan oleh birokrasi pemerintah. Pada kegiatan tujuan pemasaran potensi wilayah, kegiatan ini lebih cocok dilakukan oleh tenaga profesional karena kegiatan pemasaran lebih membutuhkan adanya kemampuan marketing yang mengadopsi nilai-nilai entrepreneurship dari lembaga bisnis, dan kalangan tenaga profesional biasanya memiliki kemampuan tersebut. Sedangkan pada kegiatan tujuan pembangunan dengan penekanan pada sinkronisasi dan pensinergian program pembangunan ekonomi antar daerah sebaiknya dilakukan oleh para birokrat di level SKPD terkait sesuai dengan bidang pembangunan yang dikerjasamakan. Misalnyam apabila disepakati melakukan kerjasama di bidang kesehatan, maka yang melaksanakan kerjasama tersebut adalah para birokrat di jajaran SKPD yang membidangi masalah kesehatan di masingmasing kabupaten. Hasil ini diharapkan akan menjadi lebih efektif karena merekalah yang sebenarnya mengetahui berbagai permasalahan serta memiliki sumberdaya yang cukup guna menyelesaikan hal tersebut. Dengan melakukan pembagian tugas semacam ini kinerja lembaga kerjasama antar daerah BARLINGMASCAKEB diharapkan menjadi lebih optimal.

\section{Kerangka Regulasi}

Kerangka regulasi dari lembaga kerjasama antar daerah BARLINGMASCAKEB hanya mengatur perjanjian induk (umum) dalam bentuk Keputusan Bersama Bupati lima kabupaten yang bersepakat untuk bekerjasama.

Tujuan yang bersifat umum tersebut dapat dikelompokkan menjadi dua, yaitu; tujuan pembangunan dengan penekanan pada sinkronisasi dan pensinergian program pembangunan ekonomi antar wilayah; dan tujuan pemasaran dengan penekanan pada pemasaran potensi dan produk-produk lokal. Agar bisa mengarah pada tujuan yang lebih spesifik maka perlu dibuat suatu kerangka regulasi yang mengatur perjanjian kerjasama pada bidang-bidang pembangunan yang disepakati yang memuat apa bidang yang dikerjasamakan, siapa pelaku kerjasama, hak dan kewajiban dari masing-masing pihak yang bekerjasama, mekanisme sanksi bagi yang melanggar perjanjian, alokasi sumber pendanaan dan batas waktu perjanjian dilangsungkan. Dengan kerangka regulasi semacam ini diharapkan dapat menjamin adanya kepastian kegiatan kerjasama serta hasil-hasil yang akan dicapainya.

Pada kasus kerjasama antara daerah BARLINGMASCAKEB kerangka regulasi hanya mengatur perjanjian induk. Namun perjanjian induk ini perlu ditindaklanjuti dengan membuat kerangka regulasi yang mengatur hal-hal yang lebih bersifat teknis berupa perjanjian kerjasama untuk menyelesaikan persoalan yang lebih spesifik antar SKPD di masing-masing kabupaten anggota.

\section{Sumber Pendanaan}

Sebagaimana organisasi lain, pendanaan menjadi masalah krusial bagi keberlangsungan lembaga kerjasama antar daerah BARLINGMASCAKEB. Selama ini dalam menjalankan aktivitasnya lembaga ini hanya mengandalkan dana iuran dari kabupatan anggota. Besarnya iuran pada 2003 dan 2004 sebesar 100 juta tiap kabupaten, namun pada 2005 besarnya iuran disepakati untuk dinaikkan menjadi 150 juta tiap anggota. Karena tidak ada aturan perundangan 
yang mengatur, masing-masing daerah mengalokasikan dana iuran tersebut melalui APBD pada pos-pos yang berbeda. Ada yang melalui alokasi belanja hibah atau belanja bantuan sosial. Sejak keluarnya Permendagri No. 37 Tahun 2010 dan Permendagri No. 22 tahun 2011 tentang Pedoman Tata Cara Penyusunan Rencana Anggaran Pendapatan dan Belanja Daerah semua daerah anggota mengalokasikan iuran daerah melalui pos belanja hibah.

Namun, dengan keluarnya Permendagri No. 32 Tahun 2011 Tentang Pedoman Pemberian Hibah dan Bantuan Sosial yang Bersumber dari Anggaran Pendapatan Belanja Daerah, dana belanja hibah tidak lagi dapat diberikan kepada lembaga kerjasama antar daerah. Pada saat ini terjadi kebingungan bagi daerah yang memiliki lembaga kerjasama antar daerah. Mereka tidak lagi dapat mengalokasikan iuran daerah untuk kegiatan kerjasama antardaerah yang mereka lakukan. Alokasi anggaran untuk membiayai kerjasama antar daerah tidak bisa dilakukan karena alokasinya keluar dari batas wilayah hukum daerah. Karena kendala tersebut, lima kabupaten yang tergabung dalam BARLINGMASCAKEB mengalami penurunan motivasi untuk melanjutkan kerjasama yang sudah dibangun sejak tahun 2001. Politik anggaran dalam konteks demikian tidak menunjang spirit daerah untuk melakukan transaksi kerjasama yang berorientasi inovasi. Dengan kata lain, politik desentralisasi telah gagal membentuk insentif untuk melembagakan aturan main yang menjadi salah satu fondasi kerjasama antar daerah (Kwon dan Feiock, 2010).

Idealnya, lembaga kerjasama antar daerah memiliki sumber-sumber pendanaan di luar dari iuran anggota melalui APBD. Sumber pendanaan bisa berasal dari bantuan pemerintah baik pusat maupun provinsi, atau lembaga kerjasama antar daerah menggalang dana dari organisasi non pemerintah (NGO) seperti lembaga donor. Lembaga kerjasama antar daerah BARLINGMASCAKEB pernah mendapatkan bantuan pendanaan dari NGO sebesar Rp 1,5 milyar untuk kegiatan operasional yang berasal dari Partnership For Governance Reform In Indonesia (PGRI). Namun, karena sifatnya hanya berupa bantuan proyek maka bantuan pendanaan ini tidak bersifat kontinyu. Belajar dari pengalaman ini mestinya pengelola lembaga kerjasama antar daerah BARLINGMASCAKEB selalu menjalin hubungan dengan berbagai organisasi kemasyarakatan yang lain terutama yang potensial dapat memberikan bantuan pendanaan bagi kegiatan operasional organisasi.

Peluang sumber pendanaan bagi lembaga kerjasama antar daerah dapat berasal dari pemerintah provinsi. Dengan keluarnya Permendagri No. 32 Tahun 2011 tentang Pedoman Pemberian Hibah dan Bantuan Sosial yang Bersumber Dari Anggaran Pendapatan Belanja Daerah, peluang itu semakin nyata. Dalam peraturan ini disebutkan bahwa pemerintah daerah baik provinsi maupun kabupaten/kota dapat memberikan dana hibah kepada pemerintah daerah yang lainnya yang berada dalam wilayah administratifnya. Peraturan ini mengakomodasi bahwa pemerintah provinsi dapat memberikan dana hibah kepada pemerintah daerah kabupaten/kota untuk kegiatan penyelenggaraan kerjasama antar daerah. Namun, lagi-lagi tidak adanya kemauan politik dari pemerintah dalam hal ini provinsi menjadikan peluang bagi lembaga kerjasama antar daerah untuk mendapatkan sumber pendanaan menjadi hilang. Tidak adanya kepastian sumber pendanaan bagi lembaga kerjasama antardaerah tidak hanya berpengaruh terhadap capaian kinerja dari lembaga tersebut, namun lebih dari itu dapat berpengaruh terhadap eksistensi dari lembaga tersebut.

\section{Sistem Pendukung}

Untuk bisa dapat tetap eksis, lembaga kerjasama antar daerah harus memiliki jaringan yang kuat baik kepada lembaga pemerintah maupun kepada lembaga non pemerintah yang lainnya. Jaringan ini mutlak diperlukan agar eksistensi lembaga dapat terjaga. Beberapa lembaga yang perlu dibangun jaringannya sebagai sistem pendukung dari lembaga kerjasama antar daerah adalah pemerintah pusat, pemerintah provinsi, lembaga donor, dan sesama lembaga kerjasama antar daerah yang lain.

Peran dari pemerintah pusat, pemerintah provinsi dan lembaga donor telah dibahas pada sub bab diatas. Sub bagian ini akan membahas pentingnya membangun jaringan dengan sesama lembaga kerjama antardaerah. Terkoneksinya hubungan antar lembaga kerjasama antar daerah sangat membantu keberlangsungan dari lembaga tersebut. Inter-koneksi dapat dilakukan dengan komunikasi melalui telepon atau surat menyurat antar pengelola. Namun, dalam era teknologi sekarang ini inter-koneksi lebih 
afdol apabila dilakukan dengan membuka situs resmi internet yang saling terhubung diantara lembaga kerjasama antar daerah.

Banyak manfaat yang dapat diperoleh apabila inter-koneksi ini terjalin. Antar lembaga kerjasama dapat melakukan brainstorming (curah pendapat) mengenai berbagai permasalahan sejenis yang dihadapi oleh para pengelola. Mereka juga sekaligus dapat melakukan benchmarking (mencontoh) terhadap kegiatan baik (best practice) yang telah dilakukan oleh lembaga kerjasama antar daerah yang lainnya. Dalam kadar tertentu terjalinnya koneksi antarlembaga ini dapat menciptakan kohesifitas di antara mereka sehingga keberadaan sesama lembaga ini dapat menjadi kelompok penekan (pressure group) bagi pemerintah pusat dalam memperjuangkan berbagai kepentingan lembaga mereka, seperti misalnya perlunya pemberian subsidi oleh pemerintah pusat kepada lembaga kerjasama antar daerah.

Keberadaan sistem pendukung pada Lembaga kerjasama antardaerah BARLINGMASCAKEB nampaknya belum menjadi perhatian oleh para pengelolanya. Lembaga ini memang telah memiliki situs resmi www.Barlingmascakeb.com, namun situs tersebut tidak terkoneksi dengan sesama situs lembaga kerjasama antar daerah lainnya. Dalam menjalankan aktivitasnya Regional Management BARLINGMASCAKEB hanya berkomunikasi dengan kabupaten anggota dan hampir tidak pernah melakukan komunikasi dengan sesama lembaga kerjasama antar daerah yang lain. Dalam menjalin hubungan dengan sistem pendukung yang lainya seperti pemerintah provinsi dan pusat, pengelola nampaknya tidak memiliki bargaining yang kuat, sehingga berbagai kemudahan yang sebenarnya dapat diperoleh apabila memiliki jaringan yang kuat dengan aktor-aktor pendukung tadi tidak pernah didapat.

Dari analisis aspek kelembagaan di atas diketahui bahwa lembaga kerjasama antar daerah BARLINGMASCAKEB tidak memiliki format kelembagaan yang jelas, dalam arti tidak ada aturan main yang pasti, seperti siapa berbuat apa dan mendapatkan apa dari para anggotanya ketika mereka bergabung dalam suatu lembaga kerjasama antar daerah. Dari format kelembagaan, lembaga kerjasama antar daerah ini tidak memiliki lingkup otoritas yang jelas. Tidak ada aturan main yang mengatur mekanisme sanksi bagi para anggota yang melanggar kesepakatan yang telah dibuat. Lembaga ini juga tidak mengatur bagaimana mekanisme pelibatan anggota dalam setiap aktivitas kerjasama yang telah disepakati bersama. Idealnya, suatu lembaga kerjasama antar daerah harus mengatur mekanisme keterlibatan anggota dalam bentuk siapa berbuat apa dan mereka mendapatkan apa dalam setiap aktivitas yang dikerjasamakan.

Aturan main dalam pemberian kontribusi pendanaan juga tidak jelas. Lembaga kerjasama ini hanya menetapkan besarnya jumlah uang yang harus dikontribusikan untuk kegiatan operasional lembaga dalam jumlah yang sama. Mekanisme ini menimbulkan kemungkinan munculnya penunggang bebas (free-riders) diantara para anggota, karena dalam bekerjasama setiap anggota pasti tidak akan mendapat manfaat (keuntungan) yang sama besar dengan anggota yang lainnya (Olson, 1965). Oleh karena itu, kontribusi pendanaan dari masing-masing anggota kepada lembaga harus dibedakan berdasarkan manfaat yang diterima oleh anggota dari keberadaan lembaga kerjasama antar daerah tersebut. Namun demikian, pada intinya lemahnya aspek kelembagaan dari lembaga kerjasama antara daerah ini lebih disebabkan karena tidak adanya kewenangan otoritas yang bersifat sentral. Lembaga kerjasama antar daerah yang dibentuk dari bawah biasanya lebih mengandalkan penggunaan strukutur organisasi yang bersifat networking (jaringan kerja), hal ini dikarenakan masingmasing anggota memiliki posisi yang setara. Namun, penggunaan struktur organisasi yang bersifat networking dalam suatu organisasi memiliki kelemahan tidak adanya pusat kendali dalam pengambilan keputusan organisasi. Struktur organisasi yang bersifat networking efektifitasnya sangat tergantung dari adanya komitmen dari masing-masing anggota untuk tetap menaati setiap keputusan yang telah dibuat bersama. Pengingkaran dari setiap kesepakatan yang telah dibuat akan berdampak pada gagalnya pencapaian tujuan organisasi yang telah ditetapkan secara bersama, karena setiap pengingkaran dari kesepakatan yang telah dibuat oleh masing-masing anggota biasanya juga tanpa dibuatkan aturan main bagaimana cara menegakkan pelaksanaan dari kesepakatan tersebut.

\section{Temuan Penelitian}

Komunikasi antar pimpinan memainkan peran yang penting untuk mengaja komitmen kerjasama (Ansell dan Gash, 2007). Dalam 
kasus kerjasama BARLINGMASCAKEB ditemukan bahwa dalam setiap agenda kerja lembaga kerjasama antar daerah tidak selalu didukung dengan kehadiran pimpinan daerah secaa fisik. Mereka selalu mengirimkan wakil dalam menghadiri berbagai kegiatan yang berhubungan dengan BARLINGMASCAKEB. Namun demikian, secara psikologis ketidakhadiran mereka telah menurunkan semangat kerja Regional Manager dan perangkatnya dalam menjalankan aktivitasnya. Menurut Ansell dan Gash (2007:558), dialog secara fisik diantara pimpinan daerah melalui face to face dapat menciptakan "thick communication" yaitu proses komunikasi yang akan mendorong para pemangku kepentingan untuk menemukan peluang-peluang yang menguntungkan bagi mereka. Kasus BARLINGMASCAKEB menyediakan pemahaman bahwa kelangkaan komunikasi di level pimpinan telah berakibat negatif terhadap spirit kerjasama antara daerah.

Temuan signifikan lainnya adalah format kelembagaan kerjasama yang tidak efektif didalam mengikat lima kabupaten untuk secara konsisten mengembangkan kepentingan kolektifnya. Format kelembagaan kerjasama antar daerah yang selama ini diterapkan lebih mengandalkan peran dari Regional Manajer sebagai pelaksana kerjasama antar daerah. Sedangkan bupati sebagai kepala daerah hanya berperan sebagai steering commitee yang bertugas pengambil keputusan-keputusan yang bersifat umum. Pengambilan kebijakan teknis dilakukan oleh dewan eksekutif yang dipimpin oleh satu orang bupati dengan anggota para kepala Bappeda dari masing-masing kabupaten anggota. Dari format kelembagaan ini SKPD teknis dari masing-masing anggota sama sekali tidak terlibat dalam kegiatan kerjasama antar daerah. Hal ini menunjukkan kelemahan yang mendasar bahwa birokrasi pemerintah daerah tidak terlibat dalam kerjasama antar daerah, tetapi aktivitas tersebut justru dilakukan oleh Regional Manajer yang tidak memiliki aparat birokrasi di masing-masing daerah. Mekanisme kerja tersebut tergambar pada gambar 1 .

Format kelembagaan kerjasama yang mengandalkan pada peran Regional Manager dalam kegiatan analisis perekonomian, investasi dan pemasaran (lihat Gambar 1) justru telah melemahkan kekuasaan birokrasi. Idealnya, lembaga kerjasama BARLINGMASCAKEB tidak menihilkan peran birokrasi tetapi menyinergikannya dalam sebuah kerangka kelembagaan yang solid. Dalam konteks ini, ketidakmampuan lembaga BARLINGMASCAKEB untuk mengatasi dilema antara kepentingan kolektif dan kepentingan individual telah memberikan pengaruh terhadap instabilitas networking yang sudah

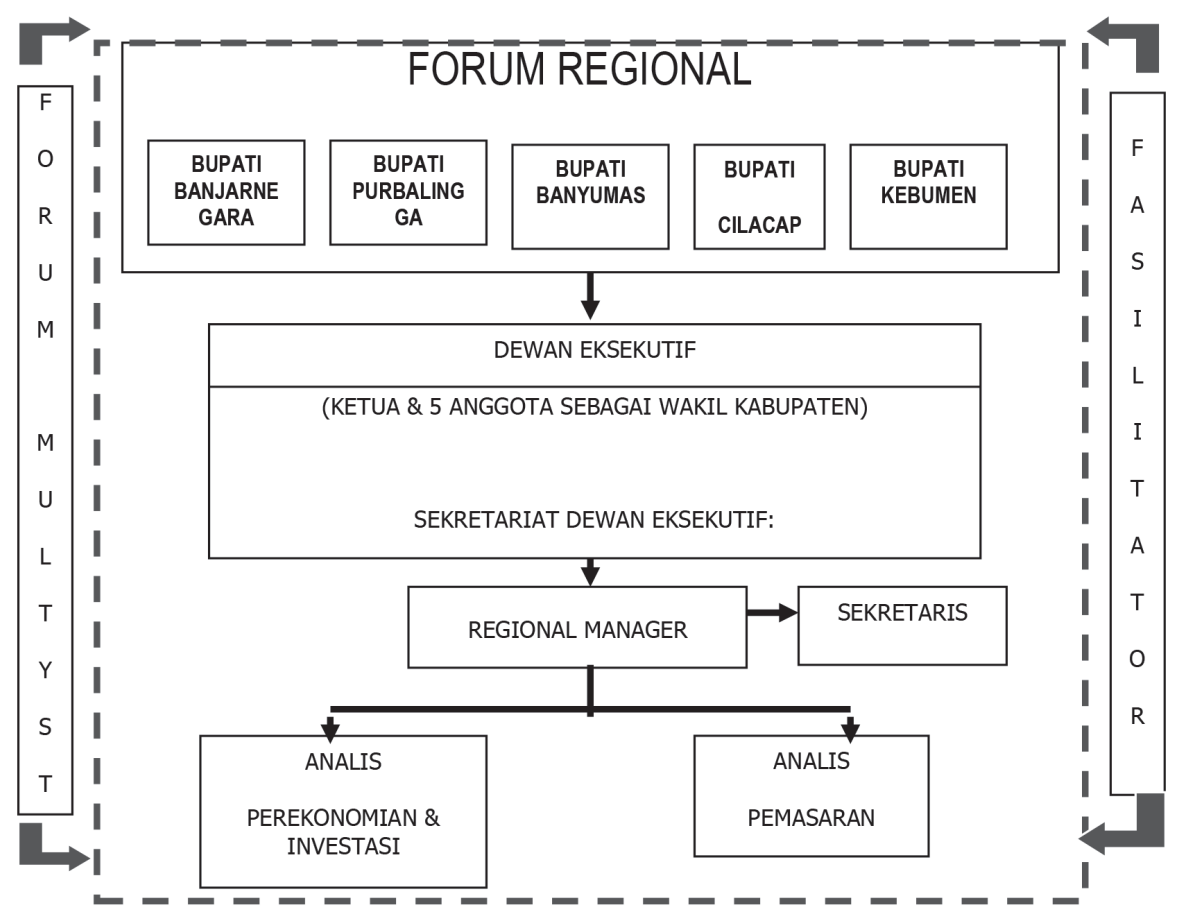

Sumber: RM. BARLINGMASCAKEB, 2011

Gambar 1 Bagan Struktur Organisasi Regional Management BARLINGMASCAKEB 
dibangun (Ibarra, Kilduff, \& Tsai, 2005). Situasi ini dalam jangka panjang dapat menurunkan komitmen kerjasama dan pada akhirnya dapat mendorong munculnya keputusan untuk menarik diri dari lembaga kerjasama (Kramer dan Noorderhaven, 2013).

Belajar dari temuan studi kasus di atas, penelitian ini menawarkan perlunya upaya restrukturisasi kelembagaan kerjasama antar daerah agar dapat memberikan kinerja yang optimal. Pada intinya setiap pelaksanaan kerjasama antar daerah harus melibatkan birokrasi pemerintah daerah dalam hal ini SKPD terkait sesuai bidang kerjasama yang akan dilakukan. Sebagai contoh, apabila akan melakukan kerjasama pengembangan pariwisata terpadu berbasis kawasan maka masing-masing SKPD yang membidangi kegiatan pariwisata di masing-masing daerah harus melakukan aksi bersama sehingga hasilnya dapat menjadi lebih optimal.

Dari hasil penggalian data di masingmasing kabupaten berkaitan dengan format kelembagaan baru kerjasama antar daerah disepakati bahwa pelaku kerjasama adalah birokrasi pemerintah daerah, tidak lagi diserahkan kepada regional manajer yang berasal dari luar birokrasi. Berikut gambaran usulan format kerjasama yang dapat dijadikan alternatif dalam pelaksanaan kerjasama antar daerah.

Pada gambar 2, menggambarkan bahwa kerjasama antar daerah dikoordinasi oleh bupati dalam Forum Regional. Kerjasama antar daerah dimulai dengan ditandatanganinya MoU antar masing-masing bupati. MoU baru dapat dianggap sah apabila telah disetujui oleh DPRD masing-masing kabupaten. Untuk menjalankan kegiatan kerjasama antar daerah dibentuk sekretariat bersama sebagai koordinator kerja sama yang ditempatkan di Kantor Bappeda salah satu kabupaten. Sekretariat bersama ini bertugas selama dua tahun dan dilakukan secara bergiliran di masing-masing kabupaten. Untuk mengkoordinasikan kegiatan kerjasama pada level anggota (kabupaten), Kantor Bappeda kabupaten berfungsi sebagai sub koordinator atau sub sekber. Tugas dari sub sekber adalah mengoordinasikan SKPD terkait yang bidang tugasnya sedang dikerjasamakan. Dengan struktur ini maka pelaksana kerjasama antar daerah adalah SKPD di masing-masing kabupaten, bukan lagi Regional Manajer sebagaimana tertuang dalam struktur kelembagaan yang lama.

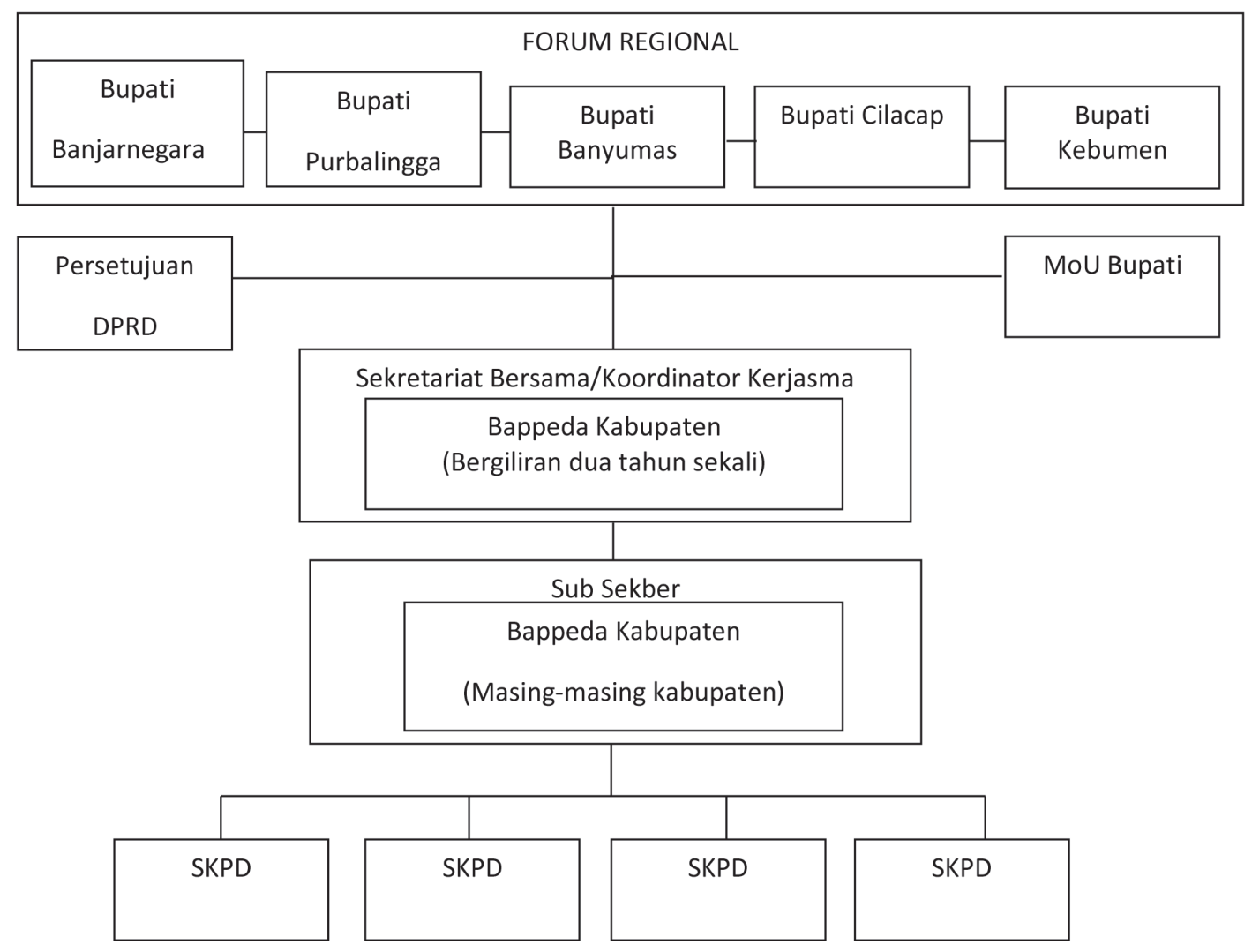

Gambar 2 Model Kelembagaan Kerjasama Antar Daerah Barlingmascakeb. 


\section{Simpulan dan Saran}

Rendahnya kinerja lembaga kerjasama antar daerah disebabkan karena aspek kelembagaan yang kurang mendukung bagi pelaksanaan kerja sama antar daerah. Beberapa faktor penyebab tidak efektifnya kerjasama antar daerah antara lain: (a) kurangnya dukungan dari pemerintah pusat dan propinsi terhadap eksistensi lembaga kerjasama antar daerah dalam bentuk rendahnya kontribusi pendanaan dan kurangnya dukungan peraturan perundangundangan yang mendukung pelaksanaan kerjasama antar daerah; (b) pelaksana dari kerjasama antar daerah tidak dilaksanakan oleh birokrasi pemerintah daerah, tetapi diserahkan kepada pihak ketiga dalam hal ini oleh Regional Manager.

Untuk menjaga sustainabilitas forum kerjasama antar daerah khususnya Barlingmasakeb, perlu dibentuk format kelembagaan baru yang lebih memberikan kewenangan yang besar bagi birokrasi pemerintah daerah sebagai pelaksana dari kerjasama antar daerah. Dengan kata lain, format baru kelembagaan kerjasama BARLINGMASCAKEB tetap memberikan ruang peran yang memadai bagi birokrasi untuk terlibat dalam kerjasama antar daerah.

\section{Ucapan Terima Kasih}

Penelitian ini dapat dilaksanakan atas Hibah Penelitian dari DIKTI pada tahun 2014 dalam Skim Penelitian Unggulan Perguruan Tinggi (PUPT). Untuk itu, tim peneliti mengucapkan terima kasih kepada DIKTI dan LPPM Unsoed atas fasilitas yang telah diterima.

\section{Daftar Pustaka}

Agranoef, R dan McGuire, M. (2003). 'Collaborative Public Management'. George Town University Press, Washington D.C.

Blair, R. dan Janousek, C.L. (2013). Collaborative Mechanisms in Interlocal Cooperation: A Longitudinal Examination. State and Local Goverment Review, Vol. 45, No 4, pp. 279-282.

Ansell, C. dan Gash, A. (2007). Collaborative Governance in Theory and Practice. Journal of Public Administration Research and Theory, Vol.18, pp. 543-571.

Fiisabiilillah, D.F., Fitria Ayu Vidayani, F.A., dan Hudalah, D. (2014). Peran Modal Sosial Dalam Kerja Sama Antar Daerah
Kartamantul. MIMBAR, Vol. 30, No. 2.

Harsanto, B.T. (2012). Analisis Kinerja Lembaga Kerjasama Antardaerah Dalam Meningkatkan Skala Ekonomi Daerah: Kajian Aspek Kelembagaan Studi Kasus Kerjasama Antar Daerah Banjarnegara, Purbalingga, Banyumas, Cilacap Dan Kebumen, Disertasi, Sekolah Pascasarjana IPB, Bogor.

Ibarra, H., Kilduff, M., dan Tsai, W. (2005). Zooming in and out: Connecting individuals and collectivities at the frontier. Organization Science, Vol. 16, No. 4, pp. 359-371.

Keban, Y.T. (2009). Kerjasama antar pemerintah daerah dalam era otonomi: Isu strategis, bentuk dan prinsip. Makalah. (http://www.bappenas.go.id/index. php download_file/view/10616/2332L) diunduh pada 15 Agustus 2014.

KPPOD. (2013). Kerjasama Antar Daerah di Bidang Perdagangan sebagai Alternatif Kebijakan Peningkatan Perekonomian Daerah. Laporan Penelitian \#4 (http:// www.kppod.org/datapdf/laporan/laporanpenelitian-4.pdf.) diunduh pada 15 Agustus 2014.

Kwon, S.W. dan Feiock, R.C. (2010). Overcoming the Barriers to Cooperation: Intergovernmental Service Agreements. Public Administration Review 7(6) : $p p$. 876-884.

Kramer, Astrid dan Niels Noorderhaven. 2013. Changes in network commitment: An experimental study about the influence of identification and centrality on network commitment. Paper presented at the 11th Public Management Research Conference, Madison, Wisconsin, June 20-22.

Masriadi. (2014). Intergovernmental Cooperation in provisioning Educational Goods and Service (Study on Intergovernmental on Providence Free Education in South Sulawesi). Journal Of Humanities and Social Science (IOSRJHSS) Vol. 19, Issue 4, Ver. III (April), pp. 32-39.

Miles, M.B., dan Huberman, A.M., (1994). 'Qualitative Data Analysis', Sage Publication, New Delhi.

Olson, Mancur, Jr. (1965). 'The Logic of Collective Action', Cambridge, MA: Harvard University Press.

Surkati, A. (2012). Otonomi Daerah sebagai Instrumen Pertumbuhan Kesejahteraan dan Peningkatan Kerjasama Antardaerah. MIMBAR, Vol. 28, No. 1 (Juni), hal. 39-46 